\title{
Modeling arsenic removal by co-precipitation under variable redox conditions
}

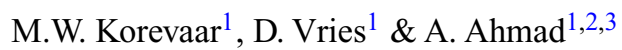 \\ ${ }^{1}$ KWR Watercycle Research Institute, Nieuwegein, The Netherlands \\ ${ }^{2}$ KTH-International Groundwater Arsenic Research Group, Department of Sustainable Development, \\ Environmental Science and Engineering, KTH Royal Institute of Technology, Stockholm, Sweden \\ ${ }^{3}$ Department of Environmental Technology, Wageningen University and Research (WUR), Wageningen, \\ The Netherlands
}

\begin{abstract}
Drinking water companies in the Netherlands are actively investigating routes to reduce arsenic (As) to $<1 \mu \mathrm{g} \mathrm{L}^{-1}$ in drinking water. Co-precipitation of As with iron during groundwater treatment is a promising method. When As(III) is present in raw water, permanganate $\left(\mathrm{MnO}_{4}\right)$ can be dosed to oxidize As(III) to As(V) in order to improve As removal efficiency. The dosages of $\mathrm{MnO}_{4}$ and $\mathrm{Fe}$ (III) to achieve $<1 \mu \mathrm{gL}^{-1} \mathrm{As}$ in the treatment effluents depend on the composition of raw water. The coprecipitation of As(III) and As(V) with ferrihydrite under variable raw water composition and redox environments, controlled by oxygen $\left(\mathrm{O}_{2}\right)$ or $\mathrm{MnO}_{4}$ is modeled in this study by the generalized double layer model, and redox equilibrium reactions. Results show that the $\mathrm{pH}$ of the treatment process is critical to determine the As removal efficiency. At $\mathrm{pH}=8$ the highest As removal is obtained, followed by $\mathrm{pH}=6$ while $\mathrm{pH}=7$ gives the least removal. $\mathrm{HCO}_{3}, \mathrm{PO}_{4}$ and $\mathrm{H}_{4} \mathrm{SO}_{4}$ hamper the adsorption of $\mathrm{As}(\mathrm{V})$. In future work, the model outcome will be assessed by experiments. Furthermore, the model will be extended with oxidation kinetics in case oxidation (by e.g. oxygen) occurs at a slower rate than the (mean) residence time of the water in the process.
\end{abstract}

\section{INTRODUCTION}

Drinking water companies in the Netherlands are actively investigating methods to reduce As to $<1 \mu \mathrm{gL}^{-1}$ in drinking water (Ahmad et al., 2014). At groundwater treatment plants (WTPs), indigenous $\mathrm{Fe}(\mathrm{II})$ in raw water is oxidized to form insoluble ferrihydrite. Also, Fe(II) or Fe(III) may be dosed in the filter influent to introduce or increase As removal. After $\mathrm{Fe}(\mathrm{II})$ gets oxidized to $\mathrm{Fe}(\mathrm{III})$ by $\mathrm{O}_{2}, \mathrm{Fe}(\mathrm{III})$ undergoes hydrolysis which results in the formation of ferrihydrite which in turn can adsorb As (coprecipitation). These As-laced ferrihydrite precipitates are then removed in a filter placed downstream. The raw water at most WTPs in the Netherlands contain As(III) in variable proportions. In order to achieve higher As removal efficiency, complete oxidation of As(III) to $\mathrm{As}(\mathrm{V})$ is necessary through dosing a strong oxidant, such as permanganate $\left(\mathrm{MnO}_{4}\right)$ (Ahmad et al., 2017). The dosages of $\mathrm{MnO}_{4}$ and $\mathrm{Fe}(\mathrm{III})$ to achieve $<1 \mu \mathrm{g} \mathrm{L}^{-1}$ As in the treatment effluent depend on the composition of raw water. The objective of this study is to model the coprecipitation of $\mathrm{As}$ (III) and As(V) with ferrihydrite under variable raw water composition and redox environments, controlled by oxygen $\left(\mathrm{O}_{2}\right)$ or $\mathrm{MnO}_{4}$.

\section{METHODS}

\subsection{Model description}

The treatment process is simplified to batch mode and the raw water composition represents typical groundwater quality in the Netherlands (see Table 1). It is assumed that As only coprecipitates with ferrihydrite. Adsorption of ferrihydrite is modeled with the Generalized Double Layer Model (DLM) based on the work of (Dzombak \& Morel, 1990). For this work, a modified PHREEQC database wateq4f is used. Arsenic adsorption constants and reactions are modified according to the average values presented in (Gustafsson \& Bhattacharya, 2007). The $\log (\mathrm{k})$ values of (de)protonation of As species is also set equal to what Gustafsson \& Bhattacharya, 2007 used to maintain consistency of the database. The adsorption of $\mathrm{H}_{4} \mathrm{SiO}_{4}$ is modeled according to (Stollenwerk et al., 2007), adsorption of carbonate is described by reactions and constants as reported by (Appelo et al., 2002). Furthermore, the system is assumed to be in thermodynamic equilibrium as most kinetics are much faster than the modeled residence time of the water. This means that $\mathrm{MnO}_{4}$ is assumed to be fully reduced to $\mathrm{Mn}$ (II) ( 1 mole $\mathrm{MnO}_{4}$ is assumed to oxidize 5 moles 
Table 1. Overview of the concentrations used in the simulations.

\begin{tabular}{lll}
\hline Compound & $\mu \mathrm{mol} / \mathrm{L}$ & $\mathrm{mg} \mathrm{L}^{-1}$ \\
\hline $\mathrm{Fe}(\mathrm{II})$ & $0-70$ & $0-3.9$ \\
$\mathrm{Mn}(\mathrm{II})$ & 3.6 & 0.2 \\
$\mathrm{As}(\mathrm{III})$ & 0.3 & 0.02 \\
$\mathrm{Ca}$ & 1497 & 60 \\
$\mathrm{Mg}$ & 329.1 & 8 \\
$\mathrm{Cl}$ & 3840.9 & 136.2 \\
$\mathrm{Na}$ & 3229.1 & 74.2 \\
$\mathrm{HCO}$ & 2458.2 & 150 \\
$\mathrm{Si}$ & 356 & 10 \\
$\mathrm{PO}_{4}$ & 5.3 & 0.5 \\
\hline
\end{tabular}

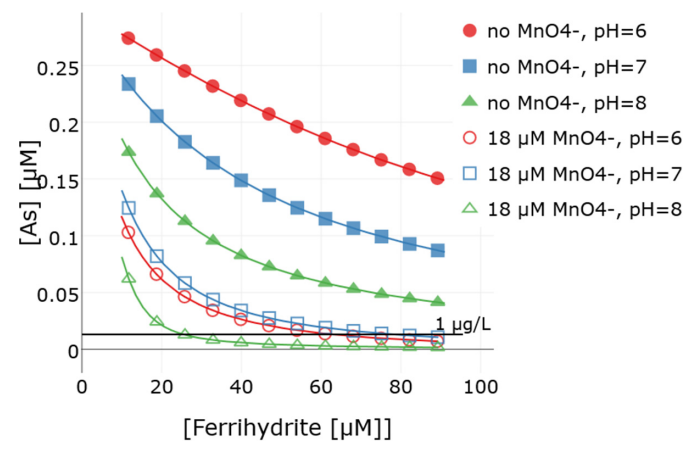

Figure 1. Removal of $\mathrm{As}(\mathrm{V})$ as function of ferrihydrite formed at different $\mathrm{pH}$ and $\mathrm{MnO}_{4}$-dosages. The horizontal line indicates the target As in drinking water in the Netherlands.

of $\mathrm{Fe}(\mathrm{II})$ to produce ferrihydrite). The only exception to this thermodynamic equilibrium is the slow oxidation of $\mathrm{As}(\mathrm{III})$ and $\mathrm{Mn}(\mathrm{II})$ by oxygen.

\section{RESULTS AND DISCUSSION}

Figure 1 presents residual $\mathrm{As}(\mathrm{V})$ as a function of the precipitated ferrihydrite at different $\mathrm{pH}$ and $\mathrm{MnO}_{4}$ dosages. The simulation shows that the amount of ferrihydrite is limited by the amount of available $\mathrm{Fe}(\mathrm{II})$ in raw water and $\mathrm{MnO}_{4}$ dose. Interestingly, $\mathrm{As}(\mathrm{V})$ removal is higher for $\mathrm{pH}=6$ compared to $\mathrm{pH}=7$, while $\mathrm{pH}=8$ yields the highest $\mathrm{As}(\mathrm{V})$ removal. This observed trend may be due to the presence of $\mathrm{H}_{4} \mathrm{SiO}_{4}$, $\mathrm{PO}_{4}$ and $\mathrm{HCO}_{3}$ in water. Figure 2 shows the removal of As(III) as function of the amount of formed ferrihydrite at different $\mathrm{pH}$ and $\mathrm{MnO}_{4}$ dosages. It confirms that the oxidation of $\mathrm{As}(\mathrm{III})$ by $\mathrm{MnO}_{4}$ significantly improves $\mathrm{As}(\mathrm{III})$ removal. Figure 3 and 4 show the effect of $\mathrm{HCO}_{3}, \mathrm{PO}_{4}$ and $\mathrm{H}_{4} \mathrm{SiO}_{4}$ on the removal of $\mathrm{As}(\mathrm{V})$ and $\mathrm{As}(\mathrm{III})$ respectively. Both figures simulate the same system but the difference is the dosage of $\mathrm{MnO}_{4}$. In Figure $3 \mathrm{MnO}_{4}$ is dosed and thus $\mathrm{As}(\mathrm{III})$ is oxidized to $\mathrm{As}(\mathrm{V})$ while in Figure $4 \mathrm{MnO}_{4}$ is not dosed. Moreover, in Figure $3 \mathrm{Fe}(\mathrm{II})$ is oxidized by $\mathrm{MnO}_{4}$ while

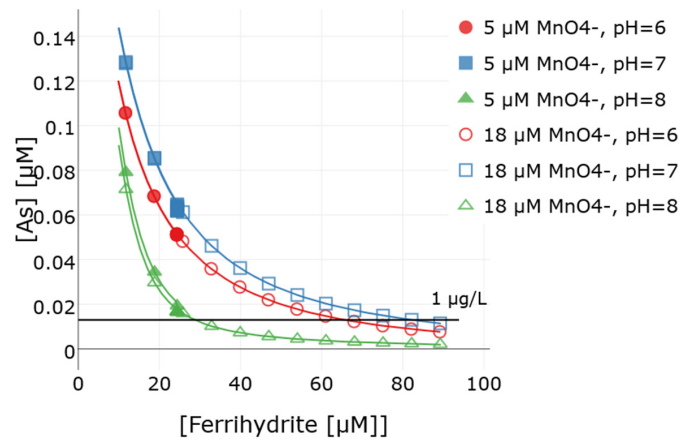

Figure 2. Removal of $\mathrm{As}(\mathrm{III})$ for different $\mathrm{pH}$ and $\mathrm{MnO}_{4}$ dosages. The horizontal line indicates the target As in drinking water in the Netherlands.

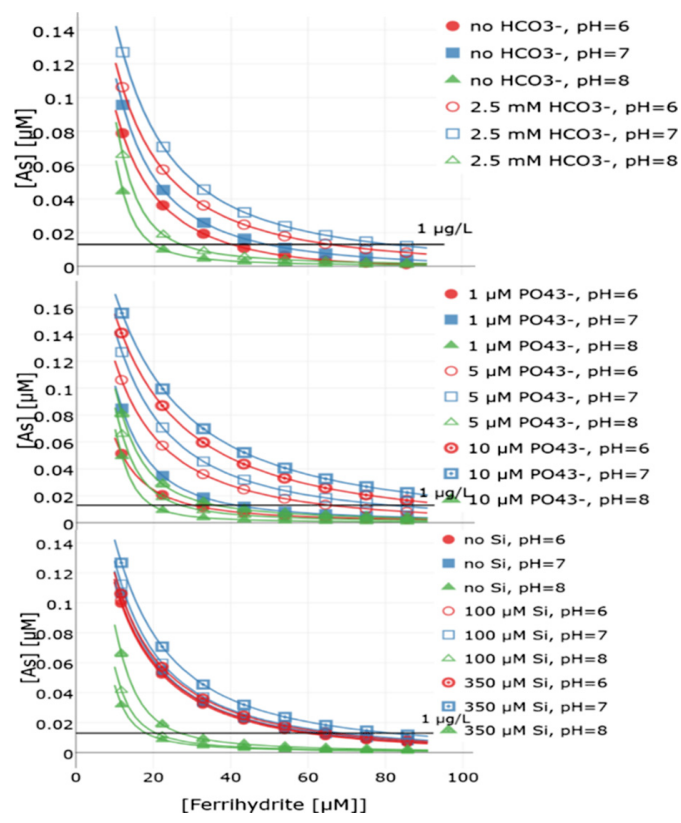

Figure 3. Removal of $\mathrm{As}(\mathrm{III})$ with $\mathrm{MnO}_{4}$ dosing for different $\mathrm{pH}$ as function of the amount of ferrihydrite formed.

in Figure $4 \mathrm{Fe}(\mathrm{II})$ is oxidized by $\mathrm{O}_{2}$. For all the cases in Figure 3, the highest removal is achieved at $\mathrm{pH}=8$, the lowest at $\mathrm{pH}=7$. The presence of both $\mathrm{HCO}_{3}, \mathrm{PO}_{4}$ and $\mathrm{H}_{4} \mathrm{SiO}_{4}$ decreases coprecipitation of As. This is in agreement with literature (Antelo et al., 2010; Appelo et al., 2002; Stollenwerk et al., 2007). Indeed, to such an extent that dosage of iron and $\mathrm{MnO}_{4}^{-}$needs to be increased to meet the goal of $1 \mu \mathrm{g} \mathrm{L}^{-1}$. E.g. due to $2.5 \mathrm{mM} \mathrm{HCO}_{3}$ at a pH of $8.0,27 \mu \mathrm{M}$ instead $20 \mu \mathrm{M}$ of ferrihydrite is required. For lower $\mathrm{pH}$ this difference is larger. It also holds for $\mathrm{PO}_{4}$ that the influence of $\mathrm{PO}_{4}$ is larger at lower $\mathrm{pH}$ and to an even stronger extent this holds for $\mathrm{H}_{4} \mathrm{SiO}_{4}$ as well.

This simulation shows that in order to achieve high process efficiency (i.e. low doses and higher removal of As) operating the treatment process at $\mathrm{pH} 8.0$ is desirable. At $\mathrm{pH}=8$ the sensitivity of the required 


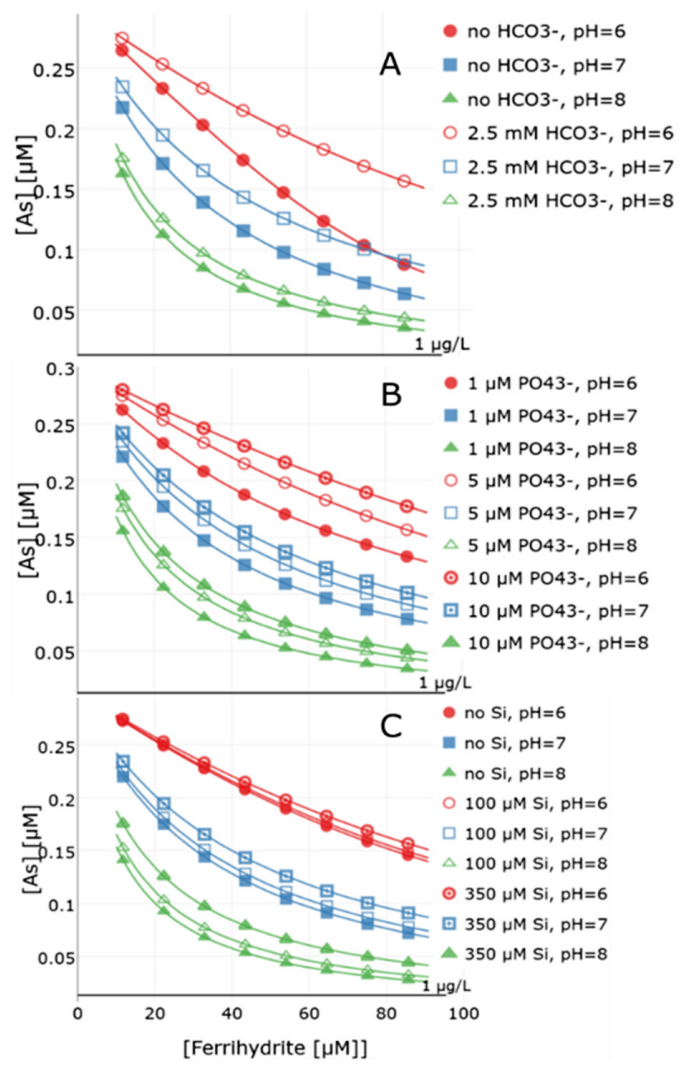

Figure 4. Removal of $\mathrm{As}(\mathrm{III})$ with $\mathrm{O}_{2}$ dosing for different $\mathrm{pH}$ as function of the amount of ferrihydrite formed. Figure $\mathrm{A}, \mathrm{B}$ and $\mathrm{C}$ illustrate the competition between the adsorption of $\mathrm{As}(\mathrm{V})$ and $\mathrm{HCO}_{3}, \mathrm{H}_{4} \mathrm{SiO}_{4}$ and $\mathrm{PO}_{4}$ respectively.

dosages to $\mathrm{HCO}_{3}, \mathrm{PO}_{4}$ and $\mathrm{H}_{4} \mathrm{SiO}_{4}$ concentrations is relatively low. The results, however, also show that the removal efficiency rapidly decreases when $\mathrm{pH}$ decreases to 7.0. This makes $\mathrm{pH}$ a critical parameter in designing and operating the As removal at groundwater treatment plants by Fe based coprecipitation under variable redox conditions.

\section{CONCLUSIONS AND OUTLOOK}

The co-precipitation of As(III) and As(V) with ferrihydrite under variable raw water composition and redox environments, controlled by oxygen $\left(\mathrm{O}_{2}\right)$ or $\mathrm{MnO}_{4}$ is modeled by the generalized double layer model, and redox equilibrium reactions. Results show that $\mathrm{As}(\mathrm{III})$ and $\mathrm{As}(\mathrm{V})$ can be removed by Fe based coprecipitation. The coprecipitation efficiency is much higher for $\mathrm{As}(\mathrm{V})$ than $\mathrm{As}(\mathrm{III})$ and this supports that As(III) should be oxidized to improve removal rates. The $\mathrm{pH}$ of the treatment process is critical to determine the As removal efficiency. At $\mathrm{pH}=8$ the highest As removal is obtained, followed by $\mathrm{pH}=6$ while $\mathrm{pH}=7$ gives the least removal. $\mathrm{HCO}_{3}, \mathrm{PO}_{4}$ and $\mathrm{H}_{4} \mathrm{SO}_{4}$ hamper the adsorption of $\mathrm{As}(\mathrm{V})$. This is true for all tested $\mathrm{pH}$ conditions, but predominantly for $\mathrm{pH}=6$ and 7.In future work, the model outcome will be assessed by experiments. Furthermore, the model will be extended with oxidation kinetics in case oxidation (by e.g. oxygen) occurs at a slower rate than the (mean) residence time of the water in the process.

\section{ACKNOWLEDGEMENT}

The authors acknowledge support from RVO (TKI Watertechnologie) and Evides, Dunea, Brabant Water, Aqua Minerals, Carus and Maltha group.

\section{REFERENCES}

Ahmad, A., Van De Wetering, S., Groenendijk, M. \& Bhattacharya, P. 2014. Advanced oxidation-coagulationfiltration $(\mathrm{AOCF})$ - an innovative treatment technology for targeting drinking water with $<1 \mu \mathrm{g} / \mathrm{L}$ of arsenic. Sustainable Development Environmental Science \& Engineering, pp. 817-819.

Ahmad, A., van Dijk, T.G., J., Van de Wetering, S., Groenendijk, M. \& Bhattacharya, P. 2017. Remediation case study: drinking water treatment by AOCF to target $<1 \mu \mathrm{g}$ $\mathrm{L}^{-1}$ effluent arsenic concentration. In: Bhattacharya, P., Polya, D.A. and Jovanovic, D. (eds) Best Practice Guide on the Control of Arsenic in Drinking Water. -IWA Publishing, UK, pp. 219-225.

Antelo, J., Fiol, S., Pérez, C., Mariño, S., Arce, F., Gondar, D. \& López, R. 2010. Analysis of phosphate adsorption onto ferrihydrite using the CD-MUSIC model. J. Colloid Interface. Sci. 347(1): 112-119.

Appelo, C.A.J., Weiden, M.J.J.V, Tournassat, C. \& Charlet, L. 2002. Surface complexation of ferrous iron and carbonate on ferrihydrite and the mobilization of arsenic. Environ. Sci. Technol. 36(14): 3096-3103.

Dzombak, D. \& Morel, F. 1990. Surface Complexation Modeling: Hydrous Ferric Oxide. John Wiley \& Sons. New York.

Gustafsson, J.P. \& Bhattacharya, P. 2007. Geochemical modelling of arsenic adsorption to oxide surfaces. In: P. Bhattacharya, A.B. Mukherjee, J. Bundschuh, R. Zevenhoven, \& R.H. Loeppert (eds) Trace Metals and Other Contaminants in the Environment. Elsevier.

Stollenwerk, K.G., Breit, G.N., Welch, A.H., Yount, J.C., Whitney, J.W., Foster, A. L., Uddin, M.N., Majumder, R.K. \& Ahmed, N. 2007. Arsenic attenuation by oxidized aquifer sediments in Bangladesh. Sci. Total Environ. 379(2-3): 133-150. 